\title{
Variability of Aerosol Optical Properties Observed at a Polluted Marine (Gosan, Korea) and a High-altitude Mountain (Lulin, Taiwan) Site in the Asian Continental Outflow
}

\author{
Soojin Park ${ }^{1}$, Sang-Woo Kim ${ }^{1 *}$, Neng-Huei Lin $^{2}$, Shantanu Kumar Pani ${ }^{2}$, Patrick J. Sheridan ${ }^{3}$, \\ Elisabeth Andrews ${ }^{3}$
}

${ }^{I}$ School of Earth and Environmental Sciences, Seoul National University, Gwanakgu, Seoul 08826, Korea

${ }^{2}$ Department of Atmospheric Sciences, National Central University, Taoyuan 32001, Taiwan

${ }^{3}$ Earth System Research Laboratory, NOAA, Boulder, CO 80305-3337, USA

\begin{abstract}
We investigated the variability of in-situ and columnar aerosol optical properties (AOPs) at two regional background sites in the Asian continental outflow from 2012 to 2014. The monthly variability of the AOPs at each site is described in terms of its relationship with regional-scale atmospheric circulation patterns and the resulting changes in air mass sources. The median aerosol scattering and absorption coefficient values for sub-10 $\mu \mathrm{m}$ particles $\left(\sigma_{\mathrm{sp}}{ }^{10 \mu \mathrm{m}}\right.$ and $\left.\sigma_{\mathrm{ap}}{ }^{10 \mu \mathrm{m}}\right)$ were larger at the polluted marine site, Gosan (GSN; $\sigma_{\mathrm{sp}}{ }^{10 \mu \mathrm{m}}: 59.94 \mathrm{Mm}^{-1}, \sigma_{\mathrm{ap}}{ }^{10 \mu \mathrm{m}}: 4.73 \mathrm{Mm}^{-1}$ ), than at the high-altitude mountain site, Lulin (LLN; $\sigma_{\mathrm{sp}}{ }^{10 \mu \mathrm{m}}: 17.07 \mathrm{Mm}^{-1}, \sigma_{\mathrm{ap}}{ }^{10 \mu \mathrm{m}}: 1.72 \mathrm{Mm}^{-1}$ ). Elevated $\sigma_{\mathrm{sp}}{ }^{10 \mu \mathrm{m}}$ and $\sigma_{\mathrm{ap}}{ }^{10 \mu \mathrm{m}}$ at GSN in May and June can be explained by the accumulation of locally emitted aerosols along with long-range transported aerosols during conditions of stagnant synoptic patterns, enhanced particle formation and subsequent growth. The significant peaks of $\sigma_{\mathrm{sp}}{ }^{10 \mu \mathrm{m}}$ and $\sigma_{\mathrm{ap}}{ }^{10 \mu \mathrm{m}}$, with median values of $50.76 \mathrm{Mm}^{-1}$ and $5.92 \mathrm{Mm}^{-1}$, at LLN during March and April are attributable to biomass burning aerosols transported from northern Indochina and southern China. The LLN site was mostly influenced by clean free troposphere air and maritime air masses during the other months, showing medians of $14.65 \pm 19.81 \mathrm{Mm}^{-1}$ and $1.46 \pm$ $1.86 \mathrm{Mm}^{-1}$ for $\sigma_{\mathrm{sp}}{ }^{10 \mu \mathrm{m}}$ and $\sigma_{\mathrm{ap}}{ }^{10 \mu \mathrm{m}}$, respectively. Lower median sub-micron to sub-10 $\mu \mathrm{m}$ ratios for the aerosol scattering and absorption coefficients at GSN ( 0.60 and 0.81 , respectively) than at LLN (0.81 and 0.91, respectively) are indicative of the larger proportion of coarse aerosols, such as sea salt and dust, at GSN. The single-scattering albedo for sub-10 $\mu \mathrm{m}$ particles showed similar median values at both sites (GSN: $0.93 \pm 0.02, \mathrm{LLN}: 0.91 \pm 0.03$ ).
\end{abstract}

Keywords: Aerosol; Aerosol scattering coefficient; Aerosol absorption coefficient; Gosan; Lulin.

\section{INTRODUCTION}

Atmospheric aerosols are of significant environmental importance because of their effects on air quality, as well as their ability to alter Earth's radiation budget, through contributing to both surface cooling and atmospheric warming by scattering and absorbing solar radiation (IPCC, 2013; Myhre et al., 2013; Allen et al., 2016). Enhanced light scattering and absorption by aerosols has a negative impact on atmospheric visibility and can also stabilize the atmosphere, resulting in inhibition of cloud formation (Ramanathan et al., 2001). The amount of light scattering and absorption by aerosols varies according to their

\footnotetext{
* Corresponding author.

Tel.: 82-2-880-6716; Fax: 82-2-883-4972

E-mail address: sangwookim@snu.ac.kr
}

concentration, chemical composition and particle size and shape, as well as several external factors, such as mixing state and hygroscopic growth (Delene and Ogren, 2002; Jacobson, 2002; Moosmüller et al., 2009). The radiative effects of aerosol particles are more important on the local or regional scale rather than the global scale because of their relatively short lifetime and uneven geographical distribution related to emissions, chemistry and weather patterns (Andrews et al., 2011; Collaud Coen et al., 2013; IPCC, 2013; Allen et al., 2016; Tsay et al., 2016; Pani et al., 2018). Thus, investigation of aerosol scattering and absorption properties on a local/regional basis is necessary to characterize the effects of aerosol particles on air quality and Earth's radiative balance, especially in regions of high loading of atmospheric aerosol (Huebert et al., 2003; Collaud Coen et al., 2013; Al-Saadi et al., 2015).

East Asia and its downwind region has experienced persistent severe pollution episodes, with particulate matter reaching unprecedentedly high levels, associated with 
increased emissions due to the fast-developing economy and urbanization (Uno et al., 2014; Al-Saadi et al., 2015; Cai et al., 2017; Zou et al., 2017; Heo et al., 2018). The abundance, physio-chemical properties and optical properties of aerosols over East Asia depend on the complicated interplay between emission sources, regionalscale atmospheric circulations and chemical processes during transport (Kim et al., 2007; Al-Saadi et al., 2015; Nam et al., 2018). Considerable progress has been made in characterizing aerosol optical properties (AOPs) at air pollution hot spots (i.e., urban/industrial areas) as well as in the Asian continental outflow over the past decades from several intensive field experiments (Huebert et al., 2003; Kim et al., 2005; Kim et al., 2014; Tao et al., 2017). However, there are still few studies on multi-year measurements with in-depth analysis of AOPs in the downwind regions of the Asian continental outflow (Collaud Coen et al., 2013; Jung et al., 2017; Uchiyama et al., 2018).

In this study, we investigate the monthly and seasonal variations of in-situ and columnar AOPs observed at two regional background sites in the Asian continental outflow, Gosan (GSN) in Korea, and Lulin (LLN) in Taiwan, from three years of continuous measurements (2012-2014). Explanation of the seasonal and intra-seasonal variability of AOPs at the two sites is given in conjunction with the transport of aerosols driven by distinct changes in regional-scale meteorological patterns.

\section{METHODS}

Surface-based measurements of aerosol optical properties (AOPs) obtained during 2012-2014 at two National Oceanic and Atmospheric Administration (NOAA) Earth System Research Laboratory (ESRL) Federated Aerosol Network sites (Andrews et al., 2018; Kim et al., 2019) within the Asian continental outflow were analyzed in this study (Fig. 1). The marine polluted site, Gosan (GSN; $33.29^{\circ} \mathrm{N}, 126.17^{\circ} \mathrm{E}, 72 \mathrm{~m}$ above mean sea level (amsl)) in South Korea, receives not only clean marine air masses from the Pacific Ocean, but also dust and pollution aerosols from the Asian continent (Kim et al., 2005, 2007). The high-altitude mountain site, Lulin (LLN; $23.51^{\circ} \mathrm{N}, 120.92^{\circ} \mathrm{E}$, $2,862 \mathrm{~m} \mathrm{amsl}$ ) in Taiwan, is mainly influenced by air masses from clean maritime regions and the free troposphere but sometimes is affected by long-range transported aerosols from biomass and industrial continental sources (Chi et al., 2010; Lin et al., 2010; Pani et al., 2017). Both sites experience heavy precipitation in summer (Yoon et al., 2010). Despite their common location within the Asian continental outflow, different variations in AOPs at GSN and LLN can be expected due to the difference in latitude and altitude in conjunction with emissions and major transport routes of aerosols.

In-situ extensive parameters, aerosol light scattering and absorption coefficients ( $\sigma_{\mathrm{sp}}$ and $\sigma_{\mathrm{ap}}$, respectively) at both sites were measured using identical instruments with similar inlet systems following the NOAA/ESRL and World Meteorological Organization (WMO) Global Atmospheric Watch (GAW) aerosol sampling protocols (Sheridan et al.,

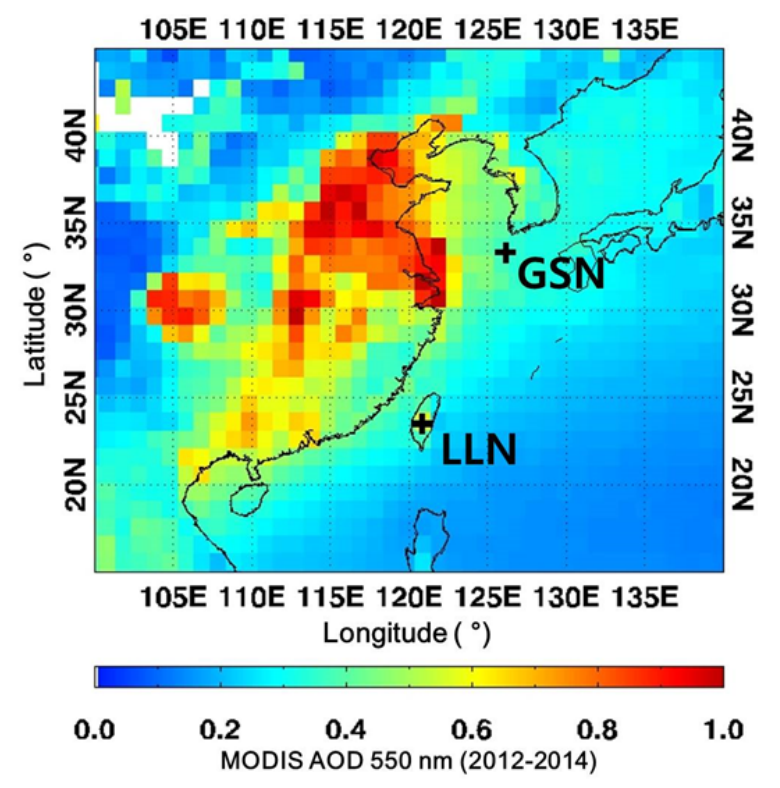

Fig. 1. MODIS AOD at $550 \mathrm{~nm}$ wavelength averaged from 2012 to 2014 and location of the observation sites; Gosan (GSN; $126.17^{\circ} \mathrm{E}, 33.29^{\circ} \mathrm{N}, 72 \mathrm{amsl}$ ) and Lulin site (LLN; $\left.120.87^{\circ} \mathrm{E}, 23.47^{\circ} \mathrm{N}, 2,868 \mathrm{amsl}\right)$.

2001; Sherman et al., 2015; WMO, 2016; Andrews et al., 2018). $\sigma_{\mathrm{sp}}$ was obtained with an integrating 3 -wavelength $(\lambda)$ nephelometer (450, 550 and $700 \mathrm{~nm}$, Model 3563; TSI, Inc.). After the corrections for angular non-idealities including truncation effects using corrections from Anderson and Ogren (1998), nephelometer-measured $\sigma_{\mathrm{sp}}$ has an uncertainty of about 8\% (Sherman et al., 2015) for hourly averages. $\sigma_{\text {ap }}$ was measured at three wavelengths (467, 528 and $652 \mathrm{~nm})$ by a Continuous Light Absorption Photometer (CLAP; Ogren et al., 2017). $\sigma_{\text {ap }}$ from CLAP instruments was adjusted for flow rate, spot size and aerosol scattering based on the method given in Bond et al. (1999). After corrections, the uncertainty of CLAP-measured $\sigma_{\text {ap }}$ is estimated to be about 4\% for hourly averages (Ogren et al., 2017). In-situ intensive parameters, such as single scattering albedo $\left[\omega=\sigma_{\mathrm{sp}} /\left(\sigma_{\mathrm{sp}}+\sigma_{\mathrm{ap}}\right)\right]$, scattering Ångström exponent $\left(\mathrm{SÅE} ; \sigma_{\mathrm{sp}} \propto \lambda^{\mathrm{S} \AA \mathrm{E}}\right)$ and absorption Ångström exponent $\left(\mathrm{A} \AA \mathrm{E} ; \sigma_{\mathrm{ap}} \propto \lambda^{\mathrm{A} \AA \mathrm{E}}\right.$ ), were calculated from $\sigma_{\mathrm{sp}}$ and $\sigma_{\mathrm{ap}}$. The least square fitting-power law was applied to $\sigma_{\mathrm{sp}}$ and $\sigma_{\mathrm{ap}}$ measured at three wavelengths to calculate $\mathrm{S} \AA \mathrm{E}$ and $\mathrm{A} \AA \mathrm{E}$. While variability of $\sigma_{\mathrm{sp}}$ and $\sigma_{\mathrm{ap}}$ was investigated using monthly median values of $\sigma_{\mathrm{sp}}$ at $550 \mathrm{~nm}$ and $\sigma_{\mathrm{ap}}$ at $528 \mathrm{~nm}$ wavelength, it should be noted that $\omega$ was calculated at $550 \mathrm{~nm}$ by using $\sigma_{\mathrm{sp}}$ measured at $550 \mathrm{~nm}$ and $\sigma_{\text {ap }}$ adjusted to $550 \mathrm{~nm}$ wavelength. The $\sigma_{\text {ap }}$ at $550 \mathrm{~nm}$ wavelength was calculated using the Å̊E.

Both sites deployed impactor systems, which switch every 6 minutes between sub-10 $\mu \mathrm{m}\left(\mathrm{D}_{\mathrm{p}}<10 \mu \mathrm{m}\right)$ and sub-micron $\left(D_{p}<1 \mu \mathrm{m}\right)$ aerodynamic particle diameters $\left(D_{p}\right)$, to measure $\sigma_{\mathrm{sp}}$ and $\sigma_{\mathrm{ap}}$ for both size cuts. Hereafter, $\sigma_{\mathrm{sp}} 10 \mu \mathrm{m}$ $\left(\sigma_{\mathrm{ap}}^{10 \mu \mathrm{m}}\right)$ and $\sigma_{\mathrm{sp}}{ }^{1 \mu \mathrm{m}}\left(\sigma_{\mathrm{ap}}{ }^{1 \mu \mathrm{m}}\right)$ refers to $\sigma_{\mathrm{sp}}\left(\sigma_{\mathrm{ap}}\right)$ for each size cut, respectively. In order to minimize aerosol hygroscopic effects, both $\sigma_{\text {sp }}$ and $\sigma_{\text {ap }}$ measurements were made at relative humidity $(\mathrm{RH}) \leq 40 \%$ by diluting the sample air 
with dry particle-free air. AOP extensive measurements are reported at standard temperature and pressure (STP; i.e., 273.15 K and 1013.25 hPa). Descriptions of the basic inlet design and sampling strategy are given in Sheridan et al. (2001) and WMO (2016; references therein).

Both sites were also equipped with a Cimel sun/sky radiometer, as part of AERONET (Aerosol Robotic Network; Holben et al., 1998). Column-integrated aerosol optical depth (AOD) and aerosol volume size distribution data (Level 2.0) under cloud-free conditions were analyzed in conjunction with the surface in-situ aerosol measurements.

MODIS (Moderate Resolution Imaging Spectroradiometer) aerosol products (Level 3 Collection 6; Platnick et al., 2015) and NCEP-NCAR (National Centers for Environmental Prediction) Reanalysis 1 data (Kalnay et al., 1996) were analyzed to investigate the temporal and spatial variability of aerosols and their relationship with regional-scale atmospheric circulation. To further investigate the monthly variation of AOPs at LLN, CALIPSO (Cloud-Aerosol Lidar and Infrared Pathfinder Satellite Observation) 5-km Aerosol Layer Products (Version 4, Level 2; Kim et al., 2018) and MODIS fire products (Level 2) were analyzed. Back trajectories from NOAA Air Resources Laboratory's HYSPLIT (Hybrid Single Particle Lagrangian Integrated Trajectory) model were also used for exploring potential aerosol source regions.

\section{RESULTS AND DISCUSSION}

\section{Variability of in-situ AOPs and their Relation to Regional-scale Meteorology}

The monthly variation of in-situ AOPs at GSN and LLN are shown in Fig. 2. Median and standard deviation of AOPs during the 3-year measurement period are given in Table 1. Detailed discussion on AOPs at each station follows.

\section{(a) Polluted Marine Site in Korea: Gosan (GSN)}

The overall median value of $\sigma_{\mathrm{sp}}{ }^{10 \mu \mathrm{m}}$ at $550 \mathrm{~nm}\left(\sigma_{\mathrm{ap}}{ }^{10 \mu \mathrm{m}}\right.$ at $528 \mathrm{~nm}$ in parenthesis) at GSN was $59.94 \pm 52.78 \mathrm{Mm}^{-1}$ $\left(4.73 \pm 3.64 \mathrm{Mm}^{-1}\right)$. Elevated $\sigma_{\mathrm{sp}}{ }^{10 \mu \mathrm{m}}$, ranging from 51.90 $\pm 68.35 \mathrm{Mm}^{-1}$ to $103.44 \pm 64.87 \mathrm{Mm}^{-1}$, was apparent from January to June at GSN. Distinctly elevated $\sigma_{\mathrm{sp}}$ during May and June at GSN can be explained by effects of several factors, i.e., a build-up of air pollutants under stationary regional meteorological conditions and formation of fine particles and subsequent growth (Kim et al., 2007; Kim et al., 2013, 2014). Winds over the Korean Peninsula in May and June are relatively weak, as seen from the wide geopotential height contour lines in Fig. 3. This slow, climatologically consistent eastward movement may contribute to the high extinction coefficient $\left(\sigma_{\mathrm{ep}}=\sigma_{\mathrm{sp}}+\sigma_{\mathrm{ap}}\right)$ in May and June by causing accumulation of anthropogenic aerosols transported from the Asian continent and domestic emissions in Korea.

From late autumn to early spring (i.e., NovemberMarch), the Korean Peninsula is mostly influenced by northwesterly winds from the Siberian High, which occasionally bring heavy loadings of aerosols from the Asian continent to the experimental sites of this study
(Kim et al., 2014; Uno et al., 2014). As demonstrated in many studies, the transport of Asian dust and pollution particles from the Asian continent exerts a large influence on AOPs at GSN during winter and spring (Kim et al., $2005,2008)$. The long top whiskers of $\sigma_{\mathrm{sp}}$ and $\sigma_{\mathrm{ap}}$ are indicative of high aerosol episodic events that affect GSN, especially in January, February and March (Fig. 2). Low $\sigma_{\text {ep }}$ in July and August at GSN can be explained by wet scavenging associated with a stationary front (i.e., the Changma phenomenon) and clean maritime air masses associated with winds blowing from the Pacific Ocean (Yoon et al., 2010; Fig. 4). Prevailing winds in Korea from September to November transit from south/southeast to west/northwest, bringing cleaner air masses.

The overall ratio of $\sigma_{\mathrm{sp}}{ }^{1 \mu \mathrm{m}}$ to $\sigma_{\mathrm{sp}}{ }^{10 \mu \mathrm{m}}$ showed a median value of $0.60 \pm 0.11$ at GSN, suggesting that $\sigma_{\mathrm{sp}}$ is dominated by sub-micron $\left(\mathrm{D}_{\mathrm{p}}<1 \mu \mathrm{m}\right)$ particles, but the presence of super-micron $\left(\mathrm{D}_{\mathrm{p}}>1 \mu \mathrm{m}\right)$ particles (e.g., dust or sea spray aerosol) cannot be ignored. Meanwhile, increased emissions of aerosols from combustion (e.g., house heating) may be responsible for elevated $\sigma_{\mathrm{sp}}$ and $\sigma_{\mathrm{ap}}$ during cold months (December-March). It is worth mentioning that there was no distinct monthly variation in the ratio of $\sigma_{\mathrm{ap}}{ }^{1 \mu \mathrm{m}}$ to $\sigma_{\mathrm{ap}}{ }^{10 \mu \mathrm{m}}$ at GSN $(0.81 \pm 0.10)$, which implies that the majority of light-absorption was due to sub-micron particles throughout the year.

\section{(b) High-altitude Mountain Site in Taiwan: Lulin (LLN)}

A significant peak of $\sigma_{\mathrm{sp}}{ }^{10 \mu \mathrm{m}}$ occurs at LLN in March and April $\left(50.76 \pm 51.01 \mathrm{Mm}^{-1}\right)$, and elevated $\sigma_{\mathrm{ap}}{ }^{10 \mu \mathrm{m}}$ from February to April exhibits magnitudes similar to those of GSN, ranging from $3.94 \pm 3.82$ to $7.03 \pm 6.09 \mathrm{Mm}^{-1}$. High values of $\sigma_{\mathrm{sp}}$ and $\sigma_{\mathrm{ap}}$ in March and April are due to occasional long-range transport of biomass burning aerosols (Chi et al., 2010; Liu et al., 2003; Sheu et al., 2009) from northern Indochina and southern China, which are areas with high AOD (Fig. 3). Prevailing winds at the $700 \mathrm{hPa}$ pressure level (i.e., approximately $3 \mathrm{~km}$ altitude), which is almost identical to the altitude of the LLN site, during March and April are southwesterlies (Fig. 4). Throughout the rest of the year, LLN is mostly under the influence of clean free troposphere air and clean maritime air masses from the Northwest Pacific Ocean. The $\sigma_{\mathrm{sp}}{ }^{10 \mu \mathrm{m}}$ and $\sigma_{\mathrm{ap}}{ }^{10 \mu \mathrm{m}}$ during these low aerosol loading months had median values of $14.65 \pm 19.81 \mathrm{Mm}^{-1}$ and $1.46 \pm 1.86 \mathrm{Mm}^{-1}$, respectively, with no distinct monthly variation.

The ratio of $\sigma_{\mathrm{sp}}{ }^{1 \mu \mathrm{m}}$ to $\sigma_{\mathrm{sp}}{ }^{10 \mu \mathrm{m}}$ and that of $\sigma_{\mathrm{ap}}{ }^{1 \mu \mathrm{m}}$ to $\sigma_{\mathrm{ap}}{ }^{10 \mu \mathrm{m}}$ at LLN were observed to be higher than at GSN, with values of $0.81 \pm 0.19$ and $0.91 \pm 0.19$, respectively. Owing to the high altitude of the LLN site, super-micron particles are rarely observed, as discussed in "Comparison between column and surface in-situ aerosol properties".

Due to its high altitude, air sampled at the LLN site may be from either the free troposphere (FT) or boundary layer (BL) during thermally-driven upslope flows (Andrews et al., 2011). The median value of $\sigma_{\mathrm{sp}}^{10 \mu \mathrm{m}}$ at $550 \mathrm{~nm}\left(17.07 \pm 27.12 \mathrm{Mm}^{-1}\right)$ and $\sigma_{\mathrm{ap}}{ }^{10 \mu \mathrm{m}}$ at $528 \mathrm{~nm}\left(1.72 \pm 2.87 \mathrm{Mm}^{-1}\right)$ at LLN was significantly lower than those observed at GSN (Table 1), due to the split between FT and BL contributions. For 
(a) GSN

(b) LLN

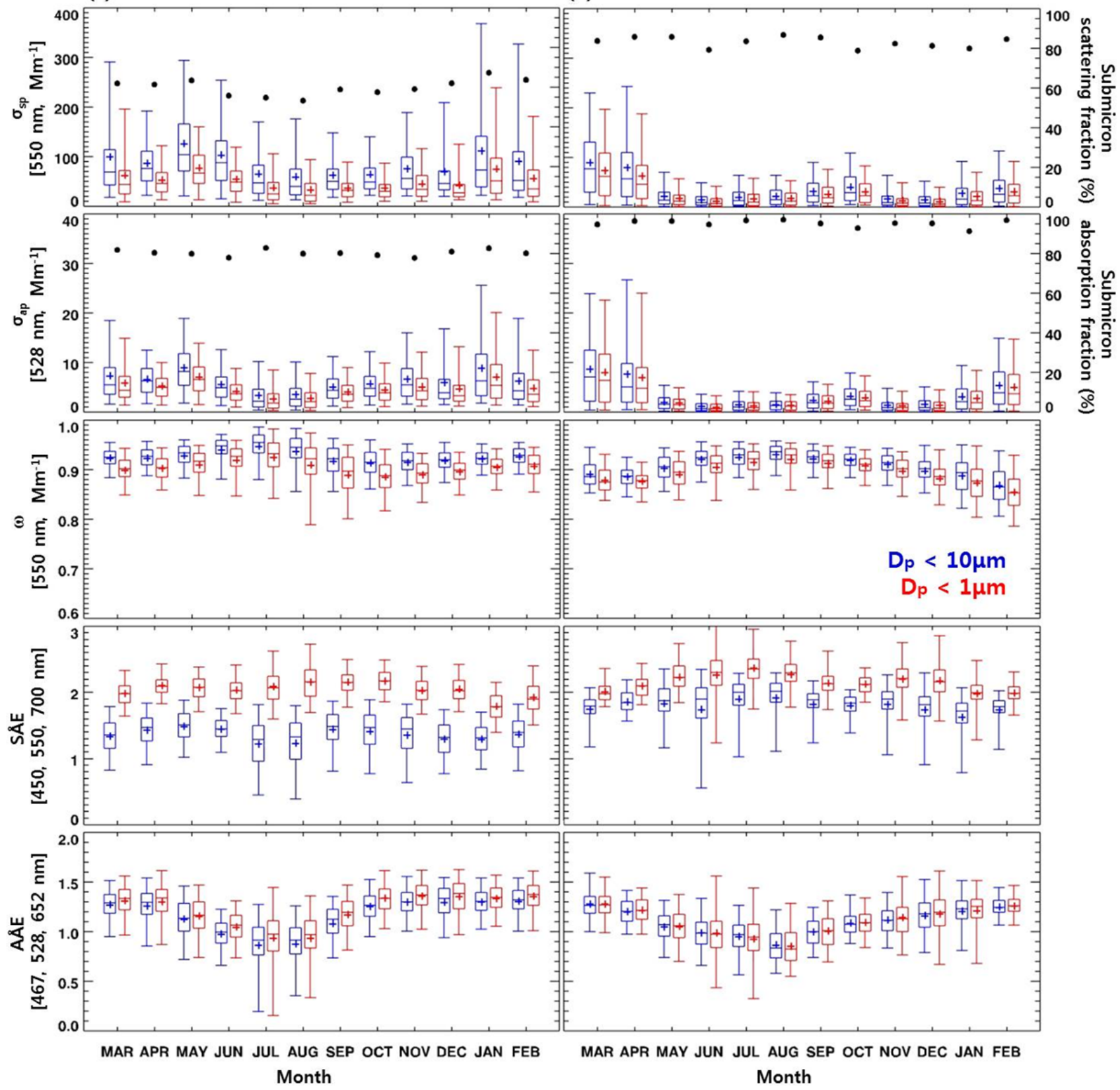

Fig. 2. Monthly variations of aerosol scattering $\left(\sigma_{\mathrm{sp}}\right)$ and absorption $\left(\sigma_{\mathrm{ap}}\right)$ coefficients, single scattering albedo $(\omega)$ and scattering and absorption Ångström exponent (SÅE and AÅE) observed at (a) Gosan (left panel) and (b) Lulin (right panel) from 2012 to 2014. Box and whiskers represent parameters of the left y-axis, and black dots represent parameters of the right $y$-axis. Whiskers represent $5^{\text {th }}$ and $95^{\text {th }}$ percentiles, and lines in boxes represent $25^{\text {th }}, 50^{\text {th }}$ (median) and $75^{\text {th }}$ percentiles. The crosses indicate the mean value. The blue and red box and whiskers indicate aerosol optical properties for sub-10 $\mu \mathrm{m}$ $\left(D_{\mathrm{p}}<10 \mu \mathrm{m}\right)$ and sub-micron $\left(\mathrm{D}_{\mathrm{p}}<1 \mu \mathrm{m}\right)$ aerosol dynamic particle ranges, respectively.

comparison, aerosol extensive parameters observed at other high-altitude sites are presented in Table 2. Measurements reported at Mt. Waliguan (WLG) in China had substantially higher values than LLN, indicative of the major emission sources in China (both dust and anthropogenic; Che et al., 2011). Meanwhile, Mt. Cimone, Italy (CMN), and Pyramid, Nepal (PYR), sites exhibited relatively high values as a result of updrafts from local emission sources (Marinoni et al., 2008; Andrews et al., 2011; Cristofanelli et al., 2014;
Schmeisser et al., 2017). The overall $\sigma_{\mathrm{sp}}{ }^{10 \mu \mathrm{m}}$ and $\sigma_{\mathrm{ap}}{ }^{10 \mu \mathrm{m}}$ at LLN were similar to those of CMN and PYR, indicating the influence of not only aerosols from long-range transport but also from local emissions.

\section{(c) Comparison of Intensive Parameters}

The overall median values of $\omega(550 \mathrm{~nm})$ for sub-10 $\mu \mathrm{m}$ particles at GSN $(0.93 \pm 0.02)$ and $\operatorname{LLN}(0.91 \pm 0.03)$ were similar to the median $\omega$ values at many other NOAA/ESRL 
Table 1. Medians of aerosol optical properties measured at Gosan (GSN) and Lulin (LLN) from 2012 to 2014.

\begin{tabular}{|c|c|c|c|}
\hline Properties & & GSN & LLN \\
\hline \multirow{3}{*}{$\sigma_{\mathrm{sp}}\left[550 \mathrm{~nm}, \mathrm{Mm}^{-1}\right]$} & $\mathrm{D}_{\mathrm{p}}<10 \mu \mathrm{m}\left(\sigma_{\mathrm{sp}}{ }^{10 \mu \mathrm{m}}\right)$ & $59.94 \pm 52.78$ & $17.07 \pm 27.12$ \\
\hline & $\mathrm{D}_{\mathrm{p}}<1 \mu \mathrm{m}\left(\sigma_{\mathrm{sp}} 1 \mu \mathrm{m}\right)$ & $36.56 \pm 32.43$ & $13.85 \pm 25.50$ \\
\hline & $\sigma_{\mathrm{sp}} 1 \mu \mathrm{m} / \sigma_{\mathrm{sp}} 10 \mu \mathrm{m} \quad a$ & $0.60 \pm 0.11$ & $0.81 \pm 0.19$ \\
\hline \multirow{3}{*}{$\sigma_{\mathrm{ap}}\left[528 \mathrm{~nm}, \mathrm{Mm}^{-1}\right]$} & $\mathrm{D}_{\mathrm{p}}<10 \mu \mathrm{m}\left(\sigma_{\mathrm{ap}}{ }^{10 \mu \mathrm{m}}\right)$ & $4.73 \pm 3.64$ & $1.72 \pm 2.87$ \\
\hline & $\mathrm{D}_{\mathrm{p}}<1 \mu \mathrm{m}\left(\sigma_{\mathrm{ap}}^{1 \mu \mathrm{m}}\right)$ & $3.82 \pm 2.81$ & $1.57 \pm 2.65$ \\
\hline & $\sigma_{\mathrm{ap}} 1 \mu \mathrm{m} / \sigma_{\mathrm{ap}} 10 \mu \mathrm{m} \quad b$ & $0.81 \pm 0.10$ & $0.91 \pm 0.19$ \\
\hline \multirow[t]{2}{*}{$\Omega[550 \mathrm{~nm}]$} & $\mathrm{D}_{\mathrm{p}}<10 \mu \mathrm{m}\left(\omega^{10 \mu \mathrm{m}}\right)$ & $0.93 \pm 0.02$ & $0.91 \pm 0.03$ \\
\hline & $\mathrm{D}_{\mathrm{p}}<1 \mu \mathrm{m}\left(\omega^{1 \mu \mathrm{m}}\right)$ & $0.91 \pm 0.03$ & $0.90 \pm 0.03$ \\
\hline \multirow{2}{*}{$\mathrm{S} \AA \mathrm{E}[450,550,770 \mathrm{~nm}]$} & $\mathrm{D}_{\mathrm{p}}<10 \mu \mathrm{m}\left(\mathrm{S}^{\prime} \mathrm{E}^{10 \mu \mathrm{m}}\right)$ & $1.40 \pm 0.26$ & $1.84 \pm 0.27$ \\
\hline & $\mathrm{D}_{\mathrm{p}}<1 \mu \mathrm{m}\left(\mathrm{S}^{\prime} \mathrm{E}^{1 \mu \mathrm{m}}\right)$ & $2.05 \pm 0.21$ & $2.14 \pm 0.27$ \\
\hline \multirow[t]{2}{*}{$\mathrm{AÅE}[467,528,652 \mathrm{~nm}]$} & $\mathrm{D}_{\mathrm{p}}<10 \mu \mathrm{m}\left(\mathrm{A} \AA \mathrm{E}^{10 \mu \mathrm{m}}\right)$ & $1.20 \pm 0.21$ & $1.12 \pm 0.18$ \\
\hline & $\mathrm{D}_{\mathrm{p}}<1 \mu \mathrm{m}\left(\mathrm{A}^{\prime} \mathrm{E}^{1 \mu \mathrm{m}}\right)$ & $1.26 \pm 0.22$ & $1.14 \pm 0.22$ \\
\hline
\end{tabular}

${ }^{a}$ sub-micron scattering fraction; ${ }^{b}$ sub-micron absorption fraction.

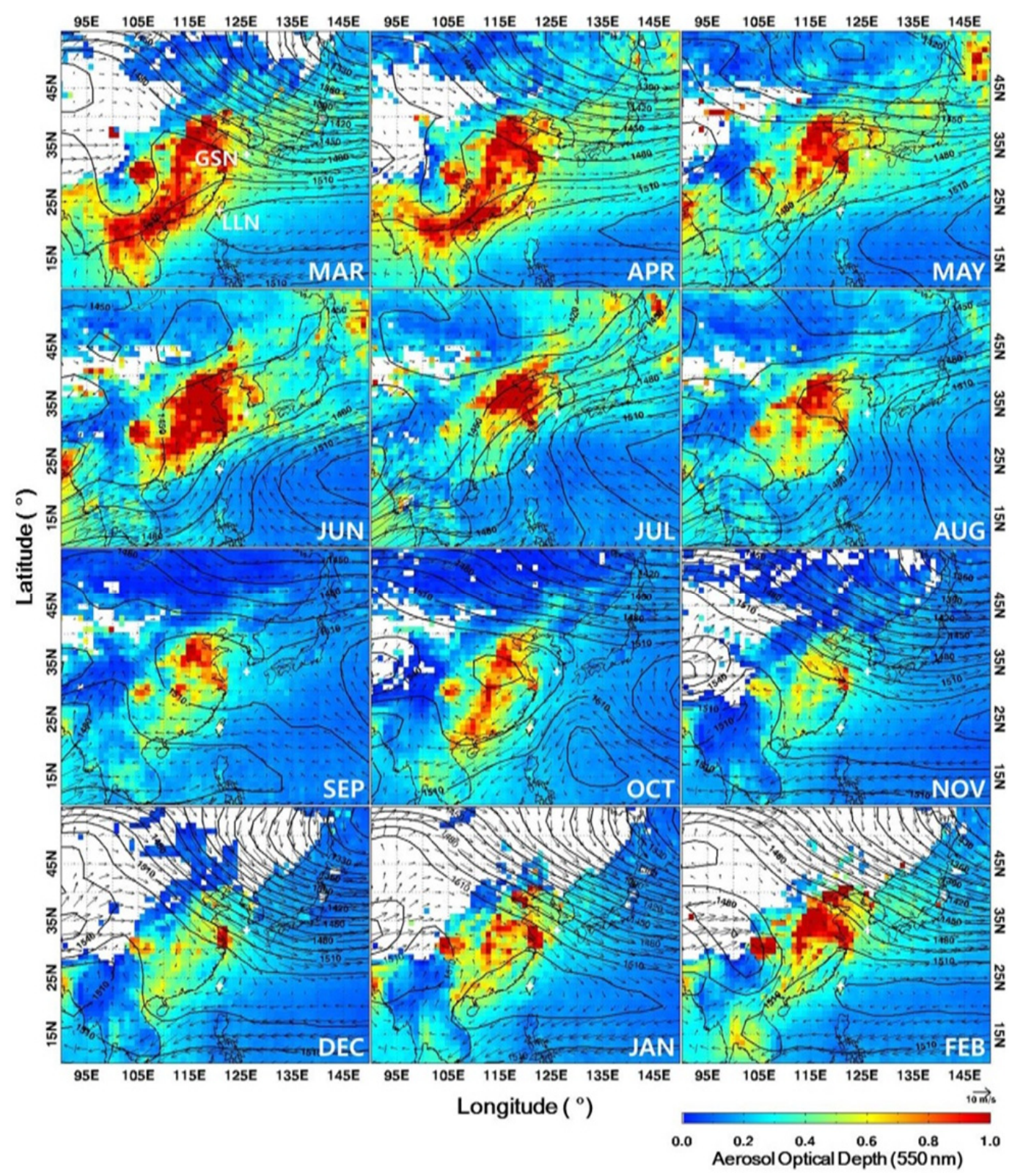

Fig. 3. Monthly averaged AOD from MODIS Level-3 data at $550 \mathrm{~nm}$ with monthly averaged geopotential height and wind vectors at $850 \mathrm{hPa}$ level over the East Asian region. Gosan and Lulin sites are indicated by white crosses. 


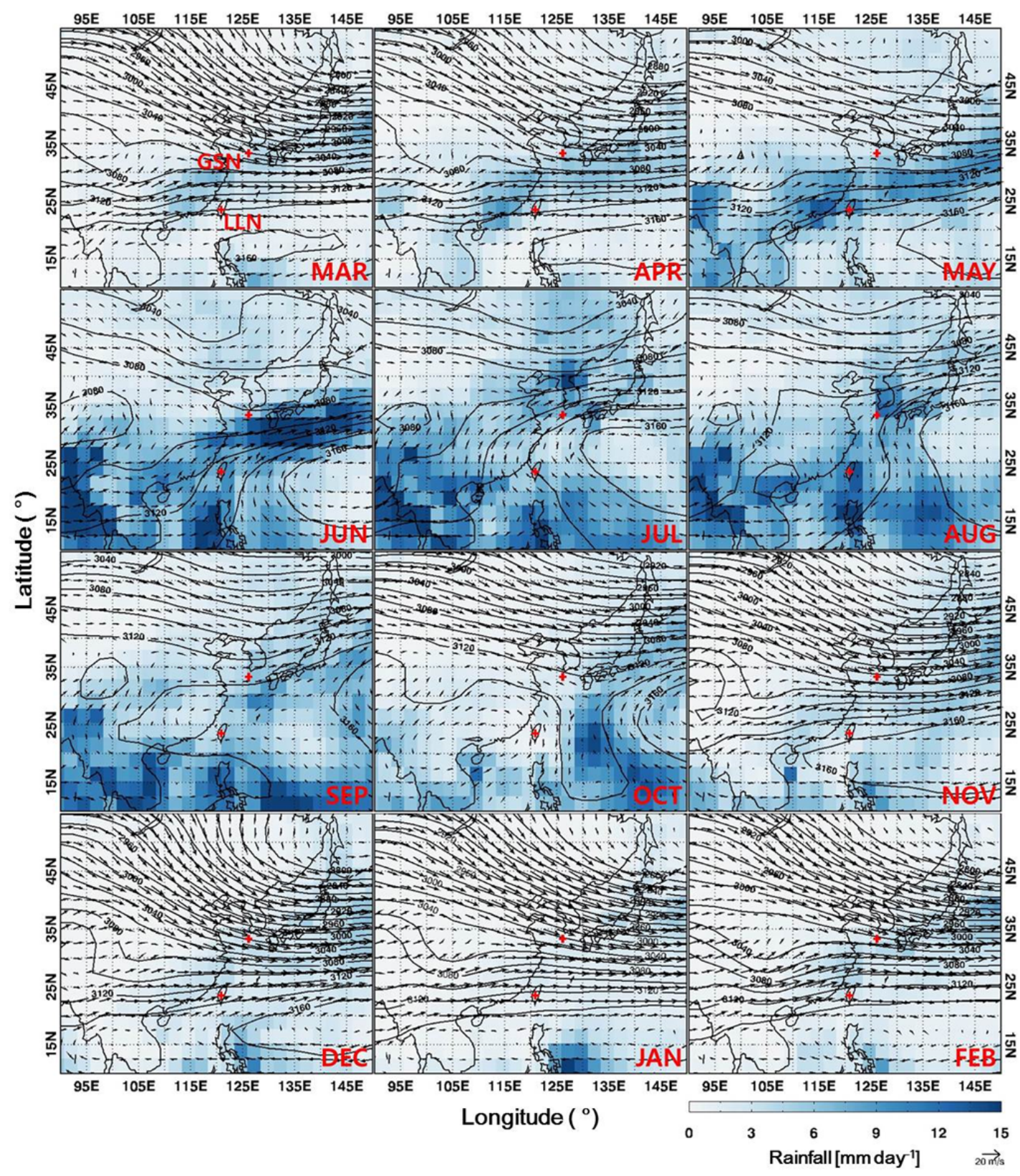

Fig. 4. Monthly averaged GPCP rainfall $\left(\mathrm{mm} \mathrm{day}^{-1}\right)$ with monthly averaged geopotential height and wind vectors at $700 \mathrm{hPa}$ level (approximately $3 \mathrm{~km}$ altitude in accordance with the altitude of the LLN site) over the East Asian region. Gosan and Lulin sites are indicated by red crosses.

Table 2. Scattering coefficient $\left(\sigma_{\mathrm{sp}}^{10 \mu \mathrm{m}}\right)$ and absorption coefficient $\left(\sigma_{\mathrm{ap}}^{10 \mu \mathrm{m}}\right)$ median values measured at various highaltitude GAW stations.

\begin{tabular}{lllllll}
\hline Station & $\begin{array}{l}\text { Altitude } \\
(\mathrm{km}, \mathrm{amsl})\end{array}$ & Period & $\begin{array}{l}\sigma_{\mathrm{sp}}{ }^{10 \mu \mathrm{m}} \\
\left(\mathrm{Mm}^{-1}\right)\end{array}$ & $\begin{array}{l}\sigma_{\mathrm{ap}}^{10 \mu \mathrm{m}} \\
\left(\mathrm{Mm}^{-1}\right)\end{array}$ & $\omega$ & References \\
\hline Mauna Loa (MLO), Hawaii, USA & 3.397 & $2012-2013$ & 9.38 & 0.85 & 0.92 & Schmeisser et \\
Storm Peak (SPL), Colorado, USA & 3.220 & $2012-2013$ & 11.50 & 0.93 & 0.92 & al. $(2017)$ \\
Summit (SUM), Greenland & 3.238 & $2012-2013$ & 8.06 & 0.64 & 0.93 & \\
Mt. Waliguan (WLG), China & 3.816 & $2012-2013$ & 42.19 & 3.01 & 0.93 & Andrews et al. \\
Pyramid (PYR), Nepal & 5.1 & $2006-2008$ & 17.40 & 1.63 & 0.91 & $(2011)$ \\
Mt. Cimone (CMN), Italy & 2.2 & $2007-2009$ & 17.20 & 2.45 & 0.88 & \\
Jungfraujoch (JFJ), Switzerland & 3.6 & $1995-2007$ & 3.50 & 0.50 & 0.88 & \\
Izana (IZA), Spain & 2.4 & $2008-2009$ & 9.32 & 0.71 & 0.93 & \\
Whistler (WHI), Canada & 2.2 & $2008-2009$ & 3.98 & 0.54 & 0.88 & \\
\hline
\end{tabular}


network sites (Andrews et al., 2018). At LLN, the overall $\omega$ was lower than that of GSN, which coincides with the lower median $\omega$ value measured from the FT $(0.90 \pm 0.05)$, reported in Andrews et al. (2011). Temporal variation of $\omega$ was similar at GSN and LLN, peaking in summer at both sites (Fig. 2). Uchiyama et al. (2018) reported low $\omega$ during the summer at Fukuoka, Japan, and Beijing, China, which is a different seasonal variability from those at GSN and LLN. Although Fukuoka is also influenced mainly by the clean ocean air masses in summer, the steady influence of local emissions of light-absorbing aerosols year round lead to a higher contribution of light absorption in summer, resulting in lower $\omega$ (Uchiyama et al., 2018).

Larger median $\mathrm{SA}^{10 \mu \mathrm{m}}$ (1.84) and $\mathrm{S}^{1} \mathrm{E}^{1 \mu \mathrm{m}}$ (2.14) values at LLN compared to those at GSN (1.40 and 2.05, respectively) are indicative of the smaller influence of large particles at LLN, as discussed previously with the sub-micron to sub-10 $\mu \mathrm{m}$ light scattering and absorption coefficient ratios. Previous work has shown a strong correlation between these two parameters (e.g., Delene and Ogren, 2002). Both the monthly median of SÅE and ratios of sub-micron to sub-10 $\mu \mathrm{m}$ light scattering and absorption coefficients showed little variability year-round. By contrast, AÅE showed large monthly variation throughout the year at both sites. AÅE was largest in winter and/or spring but lowest in summer. AÅE values at GSN showed a larger distribution range, while AÅE at LLN had a smaller range (90\% of Å̊ ranging within $0.20-1.56$ and $0.57-$ 1.59 at GSN and LLN, respectively). AÅE reported in Uchiyama et al. (2018) showed a similar seasonal variation at both Fukuoka and Beijing, with an overall range of 0.6 to 1.5. During the summer months at GSN and LLN, monthly
A ̊E median values were smaller than 1. Bergstrom et al. (2007) reported that the wavelength dependency of lightabsorption by aerosols is less certain when $\sigma_{\text {ap }}$ is small (i.e., close to the detection limit). Accordingly, months with the smallest $\sigma_{\text {ap }}$ have AÅE smaller than 1. Another possible reason for $\mathrm{A} \AA \mathrm{E}<1$ is aging of aerosols (Chung et al., 2012; Gyawali et al., 2009). Summer in East Asia is a favorable environmental condition for aerosol aging due to the stagnant weather patterns, abundant water vapor and strong solar radiation (Kim et al., 2007).

\section{Comparison between Column and Surface in-situ Aerosol Properties}

The median AOD at $500 \mathrm{~nm}$ observed at LLN was 0.03 \pm 0.05 , which was considerably smaller than the AOD observed at GSN $(0.29 \pm 0.19)$. This is consistent with the in-situ $\sigma_{\mathrm{sp}}$ and $\sigma_{\mathrm{ap}}$ measurements (Table 1). Fig. 5 shows monthly variation of AERONET AOD at $500 \mathrm{~nm}$ wavelength and adjusted $\sigma_{\text {ep }}$ at $500 \mathrm{~nm}$ from in-situ measurements at GSN and LLN. The AOD maximum at GSN was apparent in May $(0.43 \pm 0.25)$ and June $(0.47 \pm 0.18)$, whereas the AOD minimum was in August $(0.11 \pm 0.07)$. Although discrepancies exist, the explanation of the monthly variation of in-situ extensive parameters according to the synoptic weather patterns is generally also applicable to the monthly AOD variation.

Discrepancies between columnar and surface in-situ AOPs exist due to differences in temporal sampling (AERONET AOD is only observed during clear sky conditions; Schutgens et al., 2016), measurement conditions (in-situ measurements are made at $\mathrm{RH} \leq 40 \%$ conditions, AERONET AOD at ambient RH) and vertical inhomogeneity of aerosol

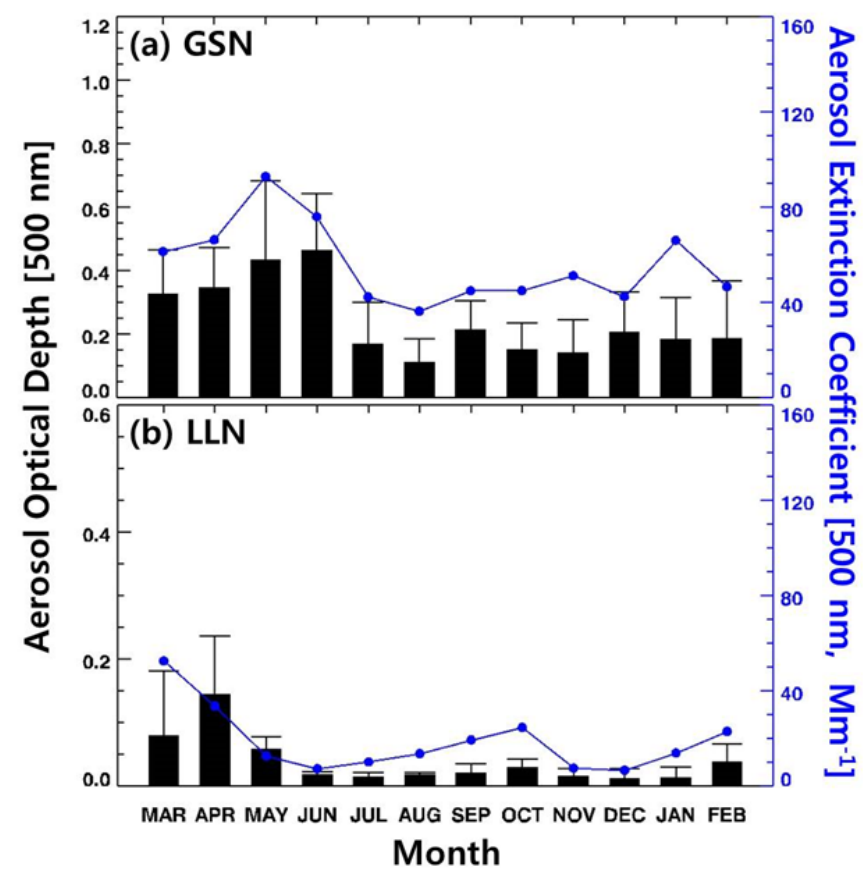

Fig. 5. Monthly median AERONET AOD observed at (a) Gosan and (b) Lulin (left y-axis, black bars) and ground-based in-situ aerosol extinction coefficient $\left(\sigma_{\mathrm{ep}}\right)$ at $500 \mathrm{~nm}$ (right y-axis, blue line). Bars represent monthly median, and whiskers indicate mean absolute deviation. 
distribution (Li et al., 2015). Previous studies including ground-based lidar measurements have shown that the majority of aerosols are distributed within the $2 \mathrm{~km}$ layer near the surface (Shimizu et al., 2016). However, elevated pollution or dust loadings within the free troposphere were also reported, resulting in discrepancies between surface in-situ and column measurements (Matthias et al., 2004; Kim et al., 2007). Another possible reason for the discrepancy between in-situ and columnar parameters is the high ambient humidity in summer. GAW recommends that in-situ observations be made at low RH $(\mathrm{RH} \leq 40 \%$; WMO, 2016; references therein); thus, in-situ aerosol AOP measurements may not exhibit the extremes due to hygroscopic growth when compared to measurements made in atmospheric conditions.

Fig. 6 shows the monthly variation of aerosol volume size distributions from AERONET sun/sky radiometer measurements. It should be noted that the color notation range in Fig. 6 is different for each site and that AERONET inversion products for cases with AOD $(440 \mathrm{~nm})<0.4$ have low reliability (Dubovik et al., 2000). When compared to other months, an increase in the coarse-mode particles with the maximum volume concentration of particles at a radius of 1-4 $\mu \mathrm{m}$ was apparent in March-May at GSN due to Asian dust episodes (Kim et al., 2008). The aerosol volume size distributions at GSN from June to December showed a minimal content of larger particles, but a relatively considerable amount of accumulation-mode particles (radius of $0.1-0.3 \mu \mathrm{m}$ ) were observed throughout the year due to the transport and hygroscopic growth of fine anthropogenic pollution aerosols, as discussed above.

On the other hand, as previously noted, the high values of $\sigma_{\mathrm{sp}}$ and $\sigma_{\mathrm{ap}}$ during spring at LLN cannot be solely attributed to Asian dust particles. The predominantly low volume concentration of coarse-mode aerosols compared to that of fine-mode aerosols at LLN supports this argument. It has been previously reported that biomass burning aerosols transported from Southeast Asia has a significant effect on aerosol measurements made at LLN (Chi et al., 2010; Pani et al., 2016). Fig. 7 presents the monthly active fire count results from MODIS Collection 6 and HYSPLIT 72-h back trajectories starting at the altitude of LLN (2,862 $\mathrm{m} \mathrm{amsl})$, and it can be inferred that transport of biomass burning aerosols by air-masses moving from high fire count regions to LLN during March and April resulted in the high $\sigma_{\mathrm{ep}}$ and AOD.

To further support this argument, CALIPSO $5-\mathrm{km}$ Aerosol Layer Product (Level 2, Version 4) data from 2012 to 2014 was analyzed. Fig. 8 shows the averaged column AOD retrieved from CALIPSO measurements over the Taiwan Strait (indicated by the green box on the map of February in Fig. 7). CALIPSO AOD from the surface to an $8 \mathrm{~km}$ altitude is 4-5 times larger than the LLN site AERONET AOD due to the majority of aerosols being concentrated within the boundary layer. On the other hand, the monthly variation of CALIPSO AOD from 3 to $8 \mathrm{~km}$ agreed well with AERONET AOD at LLN (bias $=-0.002$, $\mathrm{R}^{2}=0.92$ ), indicating that elevated aerosols within the 3 to $8 \mathrm{~km}$ layer contribute greatly to the column AOD at LLN, especially in March and April, when the AOD is extremely high. Therefore, it can be concluded that both surface and columnar AOPs at LLN in March and April are mainly influenced by biomass burning aerosols transported from Indochina across the Taiwan Strait.

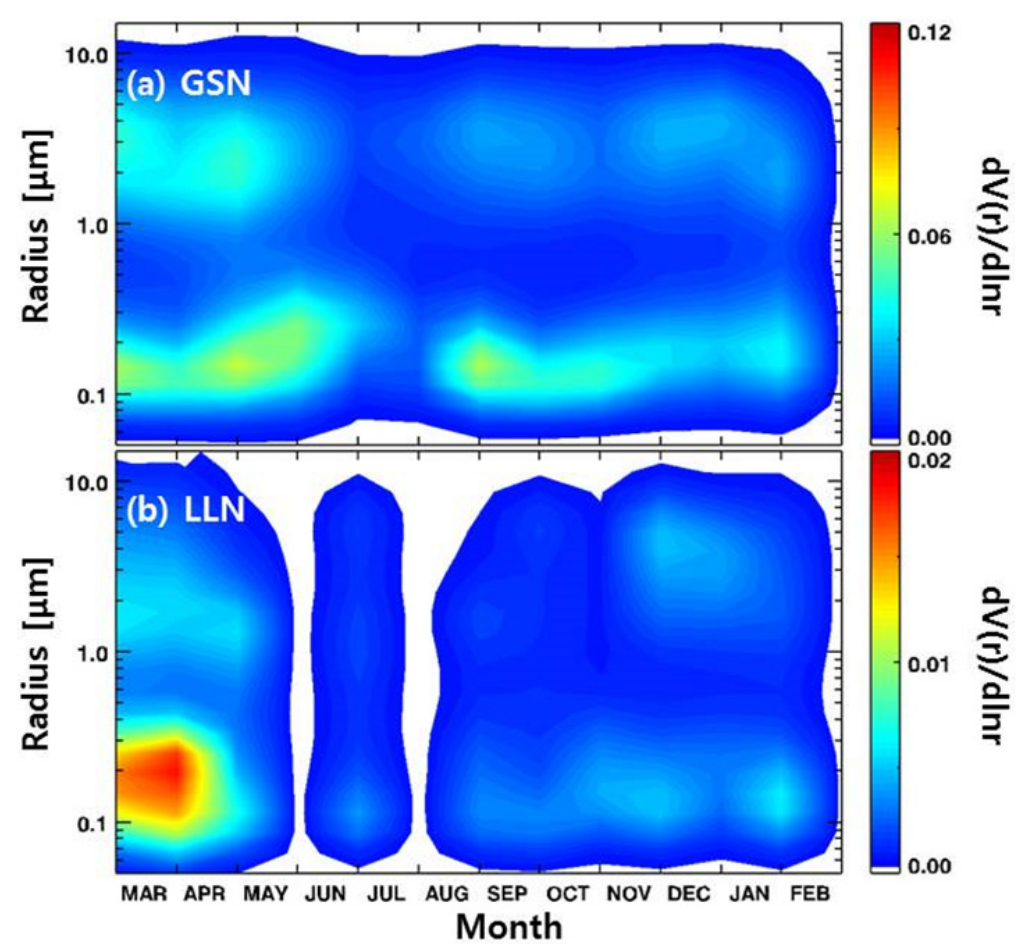

Fig. 6. AERONET sun/sky radiometer volume size distribution monthly average observed at (a) Gosan and (b) Lulin. It should be noted that the color scale is different for each site. 


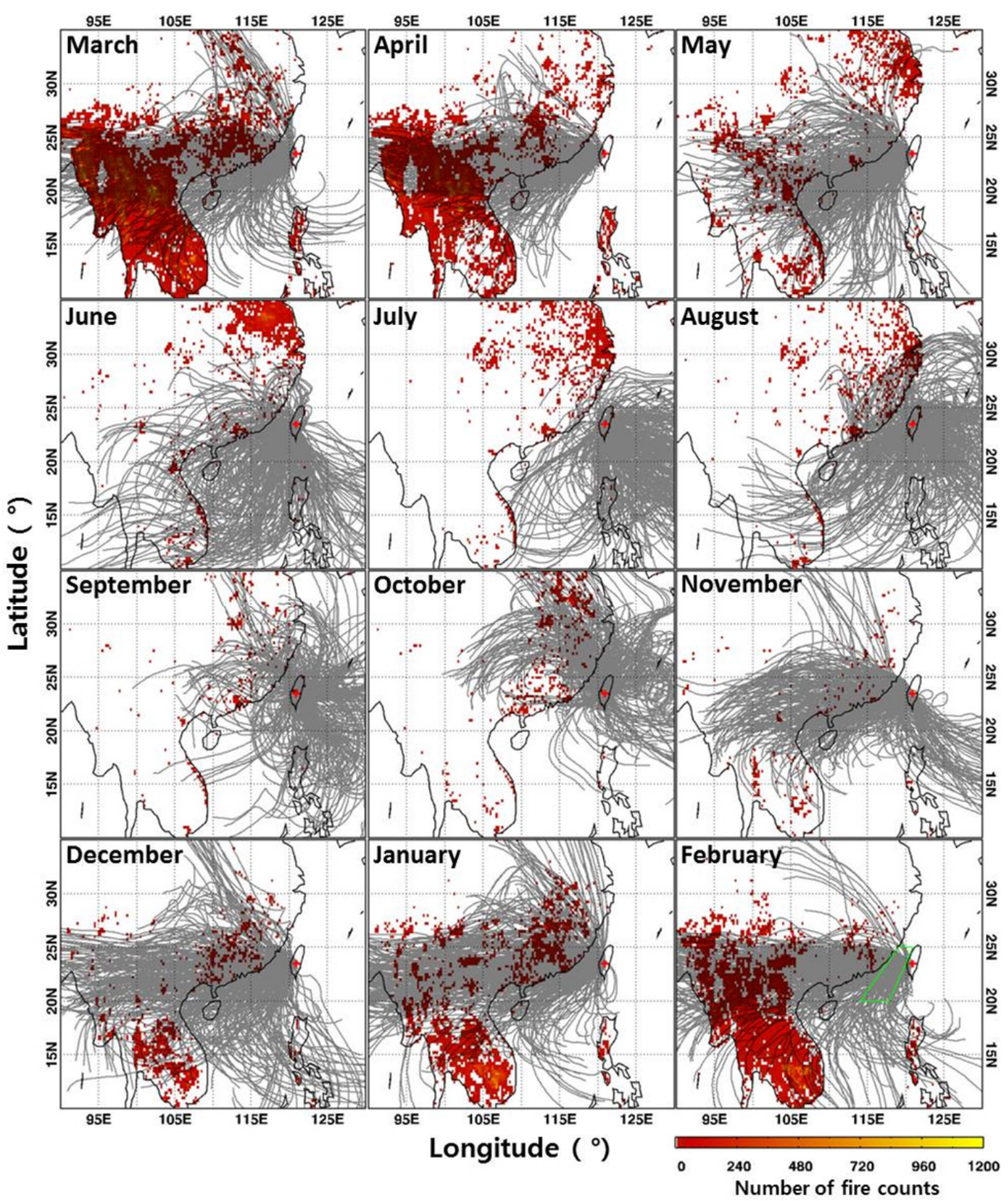

Fig. 7. Number of fire counts during 2012 to 2014 from MODIS Collection 6 Active Fire Product and 72-hour back trajectories for air plumes arriving at Lulin station.

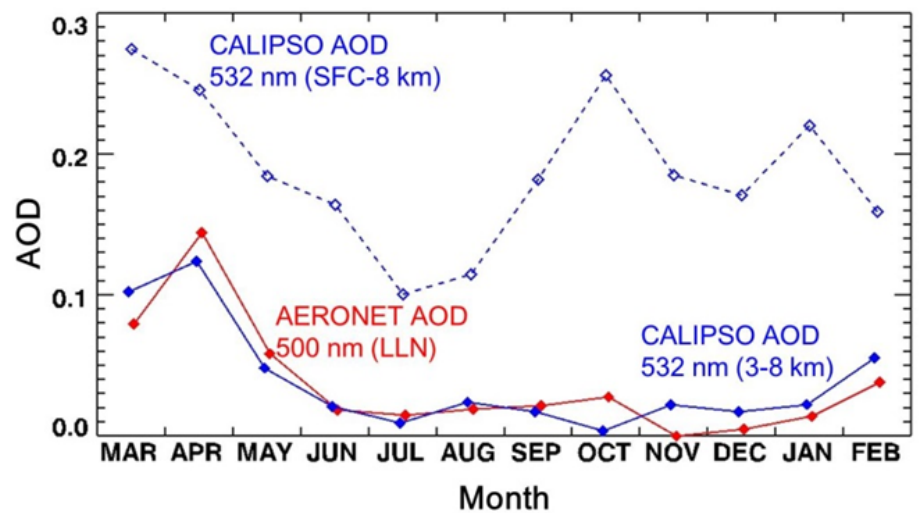

Fig. 8. Monthly variation of CALIPSO AOD averaged over Taiwan Strait (green box in Fig. 7) and AERONET sun/sky radiometer AOD at LLN. 


\section{SUMMARY}

We investigated the monthly and seasonal variations of in-situ and columnar AOPs and their relationship with the synoptic weather patterns at two sites, Gosan (GSN) and Lulin (LLN), based on 3-year continuous measurements (2012-2014). The major findings of this study are summarized below:

- Elevated $\sigma_{\mathrm{sp}}{ }^{10 \mu \mathrm{m}}$, ranging from $51.90 \mathrm{Mm}^{-1}$ to $103.44 \mathrm{Mm}^{-1}$ at $550 \mathrm{~nm}$, was apparent from January to June at GSN, with a peak during May and June.

- Although the overall median values of $\sigma_{\mathrm{sp}}{ }^{10 \mu \mathrm{m}}\left(17.07 \mathrm{Mm}^{-1}\right.$, $550 \mathrm{~nm})$ and $\sigma_{\mathrm{ap}}^{10 \mu \mathrm{m}}\left(1.72 \mathrm{Mm}^{-1}, 528 \mathrm{~nm}\right)$ at LLN were lower than at GSN, a substantially high peak for $\sigma_{\mathrm{sp}}$ $\left(68.60 \mathrm{Mm}^{-1}, 550 \mathrm{~nm}\right)$ and $\sigma_{\mathrm{ap}}\left(8.14 \mathrm{Mm}^{-1}, 528 \mathrm{~nm}\right)$ appeared during March and April. The ratio of the submicron to sub-10 $\mu \mathrm{m}$ values for $\sigma_{\mathrm{sp}}$ and $\sigma_{\mathrm{ap}}$ was 0.81 and 0.91 , respectively.

- The single scattering albedo for sub-10 $\mu \mathrm{m}$ particles $\left(\omega^{10 \mu \mathrm{m}}\right)$ did not differ greatly between GSN and LLN $(0.93 \pm 0.02$ and $0.91 \pm 0.03$, respectively).

- The maximum and minimum AOD at $500 \mathrm{~nm}$ was observed from May (0.43) to June (0.47), and in August (0.11), respectively, at GSN. The median annual AOD $(500 \mathrm{~nm})$ at LLN was 0.03 , which was considerably lower than at GSN (0.29).

- Both the $\sigma_{\text {ep }}$ and AOD peaks during March and April at LLN can be explained by biomass burning aerosols transported from Indochina, as indicated by CALIPSO measurements, MODIS fire spot data and HYSPLIT backward trajectories. The CALIPSO AOD at an altitude of 3-8 km over the Taiwan Strait and the AERONET AOD at LLN were greater than 0.1 in April.

Although the projection of emissions from the Asian continent remains profoundly uncertain, it is important to understand how changes in air pollutant emissions will influence air quality and regional climate effects in downwind regions over the next few decades. For this purpose, long-term continuous surface in-situ aerosol observations and analysis are critical to investigating the trends of AOPs and consequently, their radiative effects.

\section{ACKNOWLEDGMENTS}

This study was funded by the Korea Meteorological Administration Research and Development Program under grant KMI2017-2011. Authors are thankful to technicians and operators at Gosan and Lulin stations for maintenance and calibrations of instruments. We acknowledge the entire NASA AERONET, MODIS and CALIPSO science teams for providing data. The MODIS/Aqua Aerosol Cloud Water Vapor Ozone Monthly L3 Global 1 Deg. CMG dataset was acquired from the Level-1 and Atmosphere Archive \& Distribution System (LAADS) Distributed Active Archive Center (DAAC), located in the Goddard Space Flight Center in Greenbelt, Maryland (https://ladsweb.nascom.nasa.gov/). The CALIPSO data were obtained from the NASA Langley Research Center Atmospheric Science Data Center.

\section{REFERENCES}

Allen, R.J., Landuyt, W. and Rumbold, S.T. (2016). An increase in aerosol burden and radiative effects in a warmer world. Nat. Clim. Change 6: 269-274.

Al-Saadi, J., Carmichael, G., Crawford, J., Emmons, L., Kim, S., Song, C.K., Chang, L.S., Lee, G., Kim, J. and Park, R. (2015). NASA contributions to KORUS-AQ: An international cooperative air quality field study in Korea, https://espo.nasa.gov/home/korus-aq/content/KORUSAQ_Science_Overview_0, Last Access: 17 September 2018 .

Anderson, T.L. and Ogren, J.A. (1998). Determining aerosol radiative properties using the TSI 3563 integrating nephelometer. Aerosol Sci. Technol. 29: 57-69.

Andrews, E., Ogren, J.A., Bonasoni, P., Marinoni, A., Cuevas, E., Rodríguez, S., Sun, J.Y., Jaffe, D.A., Fischer, E.V., Baltensperger, U., Weingartner, E., Coen, M.C., Sharma, S., Macdonald, A.M., Leaitch, W.R., Lin, N.H., Laj, P., Arsov, T., Kalapov, I., Jefferson, A. and Sheridan, P. (2011). Climatology of aerosol radiative properties in the free troposphere. Atmos. Res. 102: 365-393.

Andrews, E., Sheridan, P.J., Ogren, J.A., Hageman, D., Jefferson, A., Wendell, J., Alástuey, A., Alados-Arboledas, L., Bergin, M., Ealo, M., Hallar, A.G., Hoffer, A., Kalapov, I., Keywood, M., Kim, J., Kim, S.W., Kolonjari, F., Labuschagne, C., Lin, N.H., Macdonald, A., MayolBracero, O.L., McCubbin, I.B., Pandolfi, M., Reisen, F., Sharma, S., Sherman, J.P., Sorribas, M. and Sun, J. (2018). Overview of the NOAA/ESRL federated aerosol network. Bull. Am. Meteorol. Soc. 100: 123-135.

Bergstrom, R.W., Pilewskie, P., Russell, P.B., Redemann, J., Bond, T.C., Quinn, P.K. and Sierau, B. (2007). Spectral absorption properties of atmospheric aerosols. Atmos. Chem. Phys. 7: 5937-5943.

Bond, T.C., Anderson, T.L. and Campbell, D. (1999). Calibration and intercomparison of filter-based measurements of visible light absorption by aerosols. Aerosol Sci. Technol. 30: 582-600.

Cai, W., Li, K., Liao, H., Wang, H. and Wu, L. (2017). Weather conditions conducive to Beijing severe haze more frequent under climate change. Nat. Clim. Change 7: 257-262.

Che, H., Wang, Y. and Sun, J. (2011). Aerosol optical properties at Mt. Waliguan observatory, China. Atmos. Environ. 45: 6004-6009

Chi, K.H., Lin, C.Y., Ou Yang, C.F., Wang, J.L., Lin, N.H., Sheu, G.R. and Lee, C.T. (2010). PCDD/F measurement at a high-altitude station in Central Taiwan: Evaluation of long-range transport of PCDD/Fs during the Southeast Asia biomass burning event. Environ. Sci. Technol. 44: 2954-2960.

Chung, C.E., Kim, S.W., Lee, M., Yoon, S.C. and Lee, S. (2012). Carbonaceous aerosol AAE inferred from in-situ aerosol measurements at the Gosan ABC super site, and the implications for brown carbon aerosol. Atmos. Chem. Phys. 12: 6173-6184.

Collaud Coen, M., Andrews, E., Asmi, A., Baltensperger, U., Bukowiecki, N., Day, D., Fiebig, M., Fjæraa, A.M., 
Flentje, H. and Hyvärinen, A. (2013). Aerosol decadal trends - Part 1: In-situ optical measurements at GAW and IMPROVE stations. Atmos. Chem. Phys. 13: 869894.

Cristofanelli, P., Scheel, H.E., Steinbacher, M., Saliba, M., Azzopardi, F., Ellul, R., Fröhlich, M., Tositti, L., Brattich, E., Maione, M., Calzolari, F., Duchi, R., Landi, T.C., Marinoni, A. and Bonasoni, P. (2015). Long-term surface ozone variability at Mt. Cimone WMO/GAW global station (2165 m a.s.l., Italy). Atmos. Environ. 101: 23-33.

Delene, D.J. and Ogren, J.A. (2002). Variability of aerosol optical properties at four North American surface monitoring sites. J. Atmos. Sci. 59: 1135-1150.

Dubovik, O., Smirnov, A., Holben, B., King, M., Kaufman, Y., Eck, T. and Slutsker, I. (2000). Accuracy assessments of aerosol optical properties retrieved from Aerosol Robotic Network (AERONET) Sun and sky radiance measurements. J. Geophys. Res. 105: 9791-9806.

Gyawali, M., Arnott, W. P., Lewis, K. and Moosmüller, H. (2009). In situ aerosol optics in Reno, NV, USA during and after the summer 2008 California wildfires and the influence of absorbing and non-absorbing organic coatings on spectral light absorption. Atmos. Chem. Phys. 9: 8007-8015.

Heo, J., Park, J.S., Kim, B.M., Kim, S.W., Park, R.J., Jeon, H. and Yoon, S.C. (2017). Two notable features in $\mathrm{PM}_{10}$ data and analysis of their causes. Air Qual. Atmos. Health 10: 991-998.

Holben, B.N., Eck, T., Slutsker, I., Tanre, D., Buis, J., Setzer, A., Vermote, E., Reagan, J., Kaufman, Y. and Nakajima, T. (1998). AERONET-A federated instrument network and data archive for aerosol characterization. Remote Sens. Environ. 66: 1-16.

Huebert, B.J., Bates, T., Russell, P.B., Shi, G., Kim, Y.J., Kawamura, K., Carmichael, G. and Nakajima, T. (2003). An overview of ACE-Asia: Strategies for quantifying the relationships between Asian aerosols and their climatic impacts. J. Geophys. Res. 108: 8633.

Jacobson, M.Z. (2002). Control of fossil-fuel particulate black carbon and organic matter, possibly the most effective method of slowing global warming. J. Geophys. Res. 107: ACH 16-11-ACH 16-22.

Kalnay, E., Kanamitsu, M., Kistler, R., Collins, W., Deaven, D., Gandin, L., Iredell, M., Saha, S., White, G., Woollen, J., Zhu, Y., Chelliah, M., Ebisuzaki, W., Higgins, W., Janowiak, J., Mo, K.C., Ropelewski, C., Wand, J., Leetmaa, A., Reynolds, R., Jenne, R. and Joseph, D. (1996). The NCEP/NCAR 40-year reanalysis project. Bull. Amer. Meteor. Soc. 77: 437-472.

Kim, J.H., Kim, S.W., Ogren, J.A., Sheridan, P.J., Yoon, S.C., Sharma, S. and Lin, N.H. (2019). Multiple scattering correction factor estimation for aethalometer aerosol absorption coefficient measurement. Aerosol Sci. Technol. 53: 160-171.

Kim, M.H., Omar, A.H., Tackett, J.L., Vaughan, M.A., Winker, D.M., Trepte, C.R., Hu, Y., Liu, Z., Poole, L.R., Pitts, M.C., Kar, J. and Magill, B.E. (2018). The CALIPSO version 4 automated aerosol classification and lidar ratio selection algorithm. Atmos. Meas. Tech. 11: 6107-6135.

Kim, S.W., Yoon, S., Jefferson, A., Ogren, J., Dutton, E., Won, J., Ghim, Y., Lee, B. and Han, J. (2005). Aerosol optical, chemical and physical properties at Gosan, Korea during Asian dust and pollution episodes in 2001. Atmos. Environ. 39: 39-50.

Kim, S.W., Yoon, S.C., Kim, J. and Kim, S.Y. (2007). Seasonal and monthly variations of columnar aerosol optical properties over east Asia determined from multiyear MODIS, LIDAR, and AERONET Sun/sky radiometer measurements. Atmos. Environ. 41: 1634-1651.

Kim, S.W., Yoon, S.C. and Kim, J. (2008). Columnar Asian dust particle properties observed by sun/sky radiometers from 2000 to 2006 in Korea. Atmos. Environ. 42: 492-504.

Kim, Y., Yoon, S.C., Kim, S.W., Kim, K.Y., Lim, H.C. and Ryu, J. (2013). Observation of new particle formation and growth events in Asian continental outflow. Atmos. Environ. 64: 160-168.

Kim, Y., Kim, S.W., Yoon, S.C., Kim, M.H. and Park, K.H. (2014). Aerosol properties and associated regional meteorology during winter pollution event at Gosan climate observatory, Korea. Atmos. Environ. 85: 9-17.

Li, J., Carlson, B.E. and Lacis, A.A. (2015). How well do satellite AOD observations represent the spatial and temporal variability of $\mathrm{PM}_{2.5}$ concentration for the United States? Atmos. Environ. 102: 260-273.

Lin, Y.C., Lin, C.Y. and Hsu, W.T. (2010). Observations of carbon monoxide mixing ratios at a mountain site in central Taiwan during the Asian biomass burning season. Atmos. Res. 95: 270-278.

Liu, H., Jacob, D.J., Bey, I., Yantosca, R.M., Duncan, B.N. and Sachse, G.W. (2003). Transport pathways for Asian pollution outflow over the Pacific: Interannual and seasonal variations. J. Geophys. Res. 108: 8786.

Marinoni, A., Cristofanelli, P., Calzolari, F., Roccato, F., Bonafè, U. and Bonasoni, P. (2008). Continuous measurements of aerosol physical parameters at the Mt. Cimone GAW station (2165 m asl, Italy). Sci. Total Environ. 391: 241-251.

Matthias, V., Balis, D., Bösenberg, J., Eixmann, R., Iarlori, M., Komguem, L., Mattis, I., Papayannis, A., Pappalardo, G., Perrone, M.R. and Wang, X. (2004). Vertical aerosol distribution over Europe: Statistical analysis of Raman lidar data from 10 European Aerosol Research Lidar Network (EARLINET) stations. J. Geophys. Res. 109: D18201.

Moosmüller, H., Chakrabarty, R.K. and Arnott, W.P. (2009). Aerosol light absorption and its measurement: A review. J. Quant. Spectrosc. Radiat. Transfer 110: 844878.

Myhre, G., Samset, B.H., Schulz, M., Balkanske, Y., Bauer, S., Berntsen, T.K., Bian, H., Bellouin, N., Chin, M., Diehl, T., Easter, R.C., Feichter, J., Ghan, S.j., Hauglustaine, D., Iversen, T., Kinne, S., Kirkevåg, A., Lamarque, J.F., Lin, G., Liu, X., Lund, M.T., Luo, G., Ma, X., van Noije, T., Penner, J.E., Rasch, P.J., Ruiz, A., Seland, Ø., Skeie, R.B., Stier, P., Takemura, T., 
Tsigaridis, K., Wang, P., Wang, Z., Xu, L., Yu, H., Yu, F., Yoon, J.H., Zhang, K., Zhang, H. and Zhou, C. (2013). Radiative forcing of the direct aerosol effect from AeroCom Phase II simulations. Atmos. Chem. Phys. 13: 1853-1877.

Nam, J., Kim, S.W., Park, R.J., Park, J.S. and Park, S.S. (2018). Changes in column aerosol optical depth and ground-level particulate matter concentration over East Asia. Air Qual. Atmos. Health 11: 49-60.

Ogren, J.A., Wendell, J., Andrews, E. and Sheridan, P.J. (2017). Continuous light absorption photometer for long-term studies. Atmos. Meas. Tech. 10: 4805-4818.

Pani, S.K., Wang, S.H., Lin, N.H., Tsay, S.C., Lolli, S., Chuang, M.T., Lee, C.T., Chantara, S. and Yu, J.Y. (2016). Assessment of aerosol optical property and radiative effect for the layer decoupling cases over the Northern South China Sea during the 7-SEAS/Dongsha Experiment. J. Geophys. Res. 121: 4894-4906.

Pani, S.K., Lee, C.T., Chou, C.C.K., Shimada, K., Hatakeyama, S., Takami, A., Wang, S.H. and Lin, N.H. (2017). Chemical characterization of wintertime aerosols over islands and mountains in East Asia: Impacts of the continental Asian outflow. Aerosol Air Qual. Res. 17: 3006-3036.

Pani, S.K., Lin, N.H., Chantara, S., Wang, S.H., Khamkaew, C., Prapamontol, T. and Janjai S. (2018). Radiative response of biomass-burning aerosols over and urban atmosphere in northern peninsular Southeast Asia. Sci. Total Environ. 633: 892-911.

Platnick, S., King, M., Wind, B. and Ridgway, W. (2015). MODIS atmosphere L2 joint atmosphere product. NASA MODIS Adaptive Processing System, Goddard Space Flight Center, USA, http://dx.doi.org/10.5067/MO DIS/MODATML2.006.

Ramanathan, V., Crutzen, P.J., Kiehl, J.T. and Rosenfeld, D. (2001). Aerosols, Climate, and the Hydrological cycle. Science 294: 2119-2124.

Schmeisser, L., Andrews, E., Ogren, J.A., Sheridan, P., Jefferson, A., Sharma, S., Kim, J.E., Sherman, J.P., Sorribas, M. and Kalapov, I. (2017). Classifying aerosol type using in situ surface spectral aerosol optical properties. Atmos. Chem. Phys. 17: 12097-12120.

Schutgens, N.A.J., Partridge, D.G. and Stier, P. (2016). The importance of temporal collocation for the evaluation of aerosol models with observations. Atmos. Chem. Phys. 16: 1065-1079.

Sheridan, P.J., Delene, D.J. and Ogren, J.A. (2001). Four years of continuous surface aerosol measurements from the Department of Energy's Atmospheric Radiation Measurement Program Southern Great Plains Cloud and Radiation Testbed site. J. Geophys. Res. 106: 2073520747.

Sherman, J., Sheridan, P., Ogren, J., Andrews, E., Hageman, D., Schmeisser, L., Jefferson, A. and Sharma, S. (2015).
A multi-year study of lower tropospheric aerosol variability and systematic relationships from four North American regions. Atmos. Chem. Phys. 15: 1248712517.

Sheu, G.R., Lin, N.H., Wang, J.L. and Lee, C.T. (2009). Lulin Atmospheric Background Station: A new highelevation baseline station in Taiwan. Earozoru Kenkyu 24: 84-89.

Shimizu, A., Nishizawa, T., Jin Y., Kim, S.W., Wang, Z., Batdorj, D. and Sugimoto, N. (2016). Evolution of a lidar network for tropospheric aerosol detection in East Asia. Opt. Eng. 56: 031219.

Tao, J., Zhang, L., Cao, J. and Zhang, R. (2017). A review of current knowledge concerning $\mathrm{PM}_{2.5}$ chemical composition, aerosol optical properties and their relationships across China. Atmos. Chem. Phys. 17: 9485-9518.

Tsay, S.C., Maring, H.B., Lin, N.H., Buntoung, S., Chantara, S., Chuang, H.C., Gabriel, P.M., Goodloe, C.S., Holben, B.N., Hsiao, T.C., Hsu, N.C., Janjai, S., Lau, W.K.M., Lee, C.T., Lee, J., Loftus, A.M., Nguyen, A.X., Nguyen, C.M., Pani, S.K., Pantina, P., Sayer, A.M., Tao, W.K., Wang, S.H., Welton, E.J., Wiriya, W. and Yen, M.C. (2016). Satellite-surface perspectives of air quality and aerosol-cloud effects on the environment: An overview of 7-SEAS/BASELInE. Aerosol Air Qual. Res. 16: 2581-2602.

Uchiyama, A., Chen, B., Yamazaki, A., Shi, G., Kudo, R., Nishita-Hara, C., Hayashi, M., Habib, A. and Matsunaga, T. (2018). Aerosol optical characteristics in Fukuoka and Beijing measured by integrating nephelometer and aethalometer: Comparison of source and downstream regions. J. Meteorolog. Soc. Jpn. Ser. II 96: 215-240.

Uno, I., Sugimoto, N., Shimizu, A., Yumimoto, K., Hara, Y. and Wang, Z. (2014). Record heavy $\mathrm{PM}_{2.5}$ air pollution over China in January 2013: Vertical and horizontal dimensions. Sola 10: 136-140.

WMO (2016). WMO/GAW aerosol measurement procedures, guidelines and recommendations $2^{\text {nd }}$ Edition. GAW Report NO. 227, World Meteorological Organization, Geneva, Switzerland.

Yoon, S.C., Kim, S.W., Choi, S.J. and Choi, I.J. (2010). Regional-scale relationships between aerosol and summer monsoon circulation, and precipitation over northeast Asia. Asia-Pac. J. Atmos. Sci. 46: 279-286.

Zou, Y., Wang, Y., Zhang, Y. and Koo, J.H. (2017). Arctic sea ice, Eurasia snow, and extreme winter haze in China. Sci. Adv. 3: e1602751.

Received for review, November 19, 2018 Revised, February 19, 2019 Accepted, March 18, 2019 